\title{
Germination characteristics of Salicornia patula Duval-Jouve, S. emerici Duval-Jouve, and $S$. veneta Pign. et Lausi and their occurrence in Croatia
}

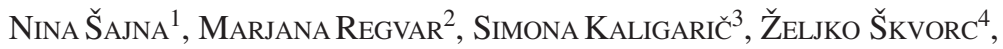 \\ MitJA KALIGARIČ ${ }^{1 *}$ \\ ${ }^{1}$ Department of Biology, Faculty of Natural Sciences and Mathematics, University of \\ Maribor, Koroška 160, 2000 Maribor, Slovenia \\ ${ }^{2}$ Department of Biology, Biotechnical Faculty, University of Ljubljana, Večna pot 111, \\ 1000 Ljubljana, Slovenia \\ ${ }^{3}$ The Institute of the Republic of Slovenia for Nature Conservation, Regional unit of \\ Maribor, Pobreška 20a, 2000 Maribor, Slovenia \\ ${ }^{4}$ Faculty of Forestry, University of Zagreb, Svetošimunska 25, 10000 Zagreb, Croatia
}

\begin{abstract}
According to recent molecular analyses of Salicornia, we revised the annual glassworts from the Croatian coast, classified until now only as Salicornia europaea. Two species, a diploid Salicornia patula and a tetraploid S. emerici were recognized. They can be easily distinguished by floral characters, but not only by their habitus, which varies extremely according to environmental factors. Both species differ also in seed morphology. Salicornia patula has dimorphic seeds, with larger central seeds reaching high germination rates. Germination patterns helped to explain the habitat preferences. The species rarely co-occur, however. The rare $S$. patula occupies drier habitats, on coastal mudflats or sands that are irregularly inundated. It occurs within the assoc. Suaedo maritimae-Salicornietum patulae. Salicornia emerici occupies the lowest coastal mudflats, regularly inundated, where nutrient-rich conditions prevail, and forms an almost monotypical assoc. Salicornietum emerici. Due to the synonymy of $S$. veneta with $S$. emerici, we exclude the occurrence of $S$. veneta in Croatia as an independent taxon.
\end{abstract}

Keywords: Salicornia patula, Salicornia emerici, Salicornia veneta, species description, habitat preference, Thero-Salicorniatea

\section{Introduction}

The genus Salicornia L. comprises annual glassworts of the tribe Salicornieae Dumort. (Chenopodiaceae). They are halophytic herbs with articulated succulent stems (DAVY et al.

\footnotetext{
* Corresponding author, e-mail: mitja.kaligaric@uni-mb.si

Copyright ${ }^{\circledR} 2013$ by Acta Botanica Croatica, the Faculty of Science, University of Zagreb. All rights reserved.
} 
2001) exhibiting extreme phenotypic plasticity (INGRUILLE and PEARSON 1987). The reduced leaf and flower morphology provides few taxonomical characters (KADEREIT et al. 2007), which cause difficulties in determination with standard determination keys. Another obstacle is inbreeding on one side and hybridization on the other side.

Although numerous taxa have been described in the last 250 years, BALL (1993) and STACE (1997) recognized only three species: Salicornia pusilla J. Woods (with one-flowered cymes), S. europaea L. aggr. (incl. S. ramosissima J. Woods, S. europaea L. and $S$. obscura P. W. Ball et Tutin) and S. procumbens Smith aggr. (incl. S. nitens P. W. Ball et Tutin, S. fragilis P. W. Ball et Tutin and S. dolichostachya Moss). The aggregate S. europaea represents a diploid group $(2 \mathrm{n}=18)$, a very variable group due to autogamy. The aggregate $S$. procumbens represents the tetraploid group $(2 \mathrm{n}=36)$.

Many morphometric studies have been aimed at defining European taxa (HUISKES et al. 1985, Ingruille and PeARSON 1987, IngRuille et al. 1990) while a comprehensive taxonomic classification with determination key of species found along the French coast is described by LAHONDÈRE (2004). Recently, the taxonomy and phylogeny of glassworts, based on ITS sequences and $a t p \mathrm{~B}-r b c \mathrm{~L}$ spacer (KADEREIT et al. 2006), showed that the annual and perennial glassworts (Salicornia / Sarcocornia) are one lineage. A narrower phylogenetic analysis showed that within four species of Salicornia, only two groups emerged, which corresponded with the ploidy level - diploids and tetraploids respectively (PAPINI et al. 2004). The latest most comprehensive molecular study, where ETS sequences of 164 accessions belonging to 31 taxa were elaborated, showed that all Adriatic diploids clustered in one clade ( $S$. perennans clade) and that all Italian diploids within this clade are named $S$. patula (KADEREIT et al. 2007). All Eurasian tetraploids belong to the same clade ( $S$. dolichostachya clade), where S. emerici and S. veneta (distributed in Italy) are clustered together. The newest study by KADEREIT et al. (2012) simplified the classification of annual Eurasian glassworts to only four species and ten subspecies. Salicornia patula became a synonym for $S$. perennans Willd. and both tetraploids, S. emerici and S. veneta (also previously identified as synonyms by KALIGARIČ et al. 2008), became a synonym for $S$. procumbens subsp. procumbens.

Our previous molecular and morphological study from the Gulf of Trieste, comprising the Slovenian and Italian coastlines, including the »locus classicus « of S. veneta in the Grado Lagoon, has resulted in a clear distinction between diploids and tetraploids by flow cytometry (KALIGARIČ et al. 2008). Additionally, ITS analysis of nrDNA showed only two species present ( $S$. patula and $S$. emerici), though we recognized four morphs, based on vegetative traits, in the beginning (»patula «, »emerici«, »veneta «, and »saline type «). The levels of ploidy matched to a high extent only with traits concerning floral morphology (length of the middle fertile segment, length of the lateral flower and, width of the scarious margin of the fertile segment). Additionally, BEER et al. (2010) rejected the long-believed correlation between the presence of one or two stamens and ploidy level. The morph named »veneta «, collected in the locus classicus and on the Slovenian coast near Ankaran, was not supported as a separate entity either on a molecular or on a morphological basis and it was classified in the frame of the tetraploid S. emerici (KALIGARIČ et al. 2008).

Results mentioned above give a new perspective. Tetraploids (S. emerici) appear to be more common than diploids ( $S$. patula) in the Northern Adriatic. They occupy lower mudflats, with higher moisture and inundation by regular tides (with additional flow of 
nutrients) than diploids, which occupy higher elevations in the salt marsh flooded only occasionally or even exposed to periods of drought and nutrient limitations. The commonness of tetraploids can be explained by the fact, that the sedimentary coast of the Friuli plain offers suitable conditions for tetraploid assemblages. Optimal habitats are also developed in the form of the »barene «, mostly tabular mudflats of the lagoons (e.g. of Grado and Venice), periodically flooded by the tide with nutrient-rich seawater, which are occupied by a special morph described by LAUSI (1969) as Salicornia veneta.

On the eastern Adriatic coast, comprising also the Croatian coast, the annual glassworts were classified only roughly as $S$. europaea or $S$. herbacea with no information on ploidy level (DomAC 1984, 2002). In the Red Book of the Vascular Flora of Croatia a tetraploid $S$. veneta is also mentioned, however, it is noted as »data deficient « taxon (NIKOLIĆ and TopIĆ 2004). In the actual national database of the Croatian flora (NIKOLIĆ 2007) S. veneta is cited from two localities, one from the island of Rab and another from the close proximity of Stari Grad. In the same database many localities all along the Adriatic coast are recorded for $S$. europaea.

In this study, several questions were asked concerning the determination, habitat preference, and the distribution of glassworts in Croatia: (1) Which characteristics of the seed, besides seed size, are significant for the determination of diploids and tetraploids?; (2) Do seeds from the $S$. emerici, »S. veneta « morphotype, and $S$. patula vary in their germination rate?; (3) Which species of Salicornia appear further along the southeast in Croatia, and how are they distributed?; (4) In which halophile associations do they grow? To address these questions, we combined known and new species characteristics in an extended species description with photographs. We evaluated whether differences in germination rates support the genetic distinction between diploids and tetraploids. In order to find and to determine annual glassworts further to the East, we checked some of the known Croatian coastal wetlands, where we collected data about the distribution and compared the phytosociological observations of species composition.

\section{Materials and methods}

\section{Seed characteristics}

Seeds of Salicornia emerici, S. patula, and $» S$. veneta « morphotype were collected late September to October 2005 from Ankaran (45 $\left.34^{\prime} N, 13^{\circ} 44^{\prime} E\right)$, Strunjan $\left(45^{\circ} 32^{\prime} N\right.$,

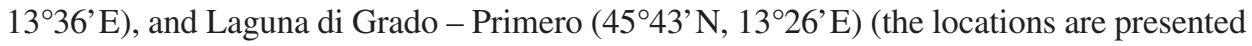
in Fig. 1). We measured seed length and width for 20 central and lateral seeds of, S. patula, $S$. emerici and the $» S$. veneta « morphotype. Additionally, we weighed 50 seeds of each species four times to obtain the seed mass. We were also prompted by the work of IBERITE (1996, 2004), who mentioned the curving of the trichomes on the seed testa as a diagnostic character, to perform observations of 10 trichomes covering the seed testa on three seeds. Observations were performed under the microscope and their length and width were noted. We did not distinguish between main and lateral seeds except in the case of S. patula. Multiple comparisons of seed characteristics were done with non-parametric Kruskal Wallis ANOVA median test. 


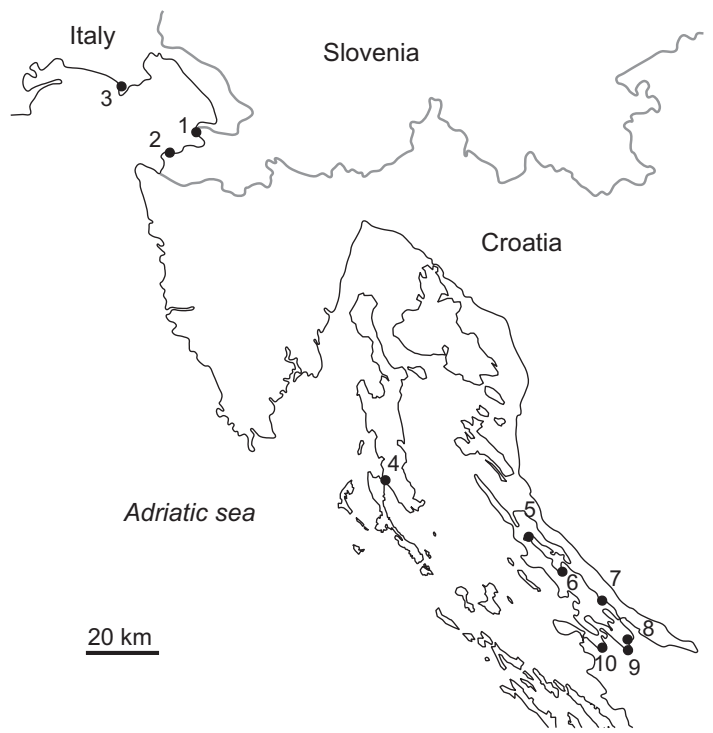

Fig. 1. Plants originating from Italian (3), Slovenian $(1,2)$, and Croatian (5-10) Salicornia populations.

\section{Germination tests}

Seeds from the same samples mentioned above were used in germination studies. Seeds did not undergo cold treatment and were dry stored at $20{ }^{\circ} \mathrm{C}$ until germination tests in March 2006. We investigated germination responses of seeds originating from the central flower and those from lateral flowers separately, since germination patterns can differ between dimorphic seeds of a single species (IMBERT 2002). Germination rate was tested in a Petri dish on a filter paper watered with $10 \mathrm{~mL}$ of deionized water to achieve the best germination response. We tested 20 seeds per dish and 3 dishes in every test, conducted in a growing chamber at $23{ }^{\circ} \mathrm{C}$ with a $16 / 8 \mathrm{~h}$ photoperiod. The effect of salinity was tested by adding sodium chloride to deionized water. BERGER (1985) stressed, in his study about germination of $S$. patula, that in the $340 \mathrm{mM} \mathrm{NaCl}$ solution central seeds were still able to germinate, while lateral seeds were not. We used the above mentioned $340 \mathrm{mM} \mathrm{NaCl}$ solution, though. Germinated seeds were counted daily and the germination rate was followed for 18 days.

\section{Investigations in Croatia}

The study areas were the following coastal wetlands in the Kvarner and Northern

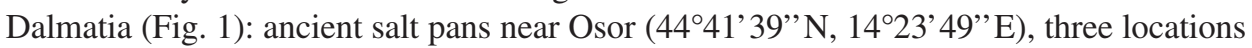

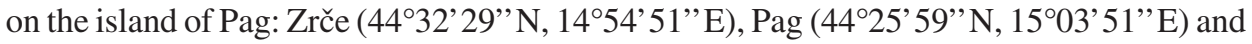

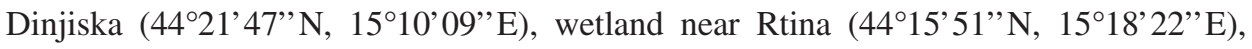
wetland and estuary near Ljubački Stanovi (near Ljubac 44 ${ }^{\circ} 14^{\prime} 45^{\prime \prime} \mathrm{N}, 15^{\circ} 17^{\prime} 15^{\prime \prime} \mathrm{E}$ ), Nin -

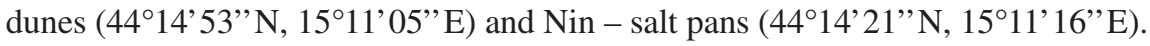

Plants were determined according to the determination key KALIGARIČ et al. (2008). Nomenclature follows IBERITE (2004) for taxa and FRONDONI and IBERITE (2002) for syntaxonomy. On each site a short vegetation survey was made. 


\section{Results}

\section{Seed characteristics}

Seed length and width for central seeds did not significantly differ among Salicornia emerici, »S. veneta " morphotype or S. patula (Kruskal - Wallis ANOVA median tests; length: $\chi^{2}=2.828, \mathrm{df}=2, \mathrm{p}=0.243$; width: $\chi^{2}=2.54$, $\mathrm{df}=2, \mathrm{p}=0.280$ ). Significant differences were shown for the length and width of lateral seeds (Kruskal - Wallis ANOVA median tests; length: $\chi^{2}=15.758, \mathrm{df}=2, \mathrm{p}<0.001$; width: $\chi^{2}=7.60, \mathrm{df}=2, \mathrm{p}=0.03$ ), herewith confirming the dimorphism of $S$. patula seeds.

The highest seed mass was found in the central seeds $(0.51 \pm 0.011 \mathrm{mg})$ from $S$. veneta, followed by seeds from $S$. patula $(0.45 \pm 0.003 \mathrm{mg})$ and $S$. emerici $(0.42 \pm 0.077 \mathrm{mg})$. Lateral seeds had a lower seed mass on general $\gg S$. veneta « morphotype: $0.32 \pm 0.010 \mathrm{mg}$; S. patula: $0.39 \pm 0.035 \mathrm{mg}$; S. emerici: $(0.34 \pm 0.005 \mathrm{mg})$. Seed dimorphism was not observed in seed mass for seeds of S. patula.

Trichome length, like width, did not significantly differ among seeds from S. emerici, $» S$. veneta « morphotype and dimorphic $S$. patula seeds (central, lateral seeds) according to Kruskal - Wallis ANOVA median tests (length: $\chi^{2}=3.445$, $\mathrm{df}=3, \mathrm{p}=0.328$; width: $\chi^{2}=$ $7.250, \mathrm{df}=3, \mathrm{p}=0,064)$.

\section{Extended species description}

The presented species description is based on the determination key from KaLIGARIČ et al. (2008) with added seed characteristics and photographs. The new nomenclature is inserted in parentheses following KADEREIT et al. (2012).

Salicornia patula (= S. perennans Willd.) is an erect plant, a few to $40 \mathrm{~cm}$ high. The branching is simple to profuse, always from the base (Fig. 3a). Generative parts are small. Short fertile shoots $(16-22 \mathrm{~mm})$ bear 7 to 9 short $($ c. $3 \mathrm{~mm}$ ) and thin (c. $2.5 \mathrm{~mm})$ fertile segments, which have distinctly convex sides (Fig. 4a). End of a segment has a narrow scarious edge $(<0.3 \mathrm{~mm})$. The inflorescence has unequal flowers with a larger central flower and distinctly smaller lateral flowers $(<2 \mathrm{~mm})$. Seed dimorphism is present with smaller lateral seeds $(<1 \mathrm{~mm})$ and bigger central seed $(1.3-1.5 \mathrm{~mm})$. Smaller seeds are dark brown, while bigger seeds are light brown.

Salicornia emerici (= S. procumbens subsp. procumbens) is usually erect, 35 to $45 \mathrm{~cm}$ high, densely branched with lower branches curving upwards (Fig. 3b). Long fertile shoots $(27-33 \mathrm{~mm}$ ) consist of 8 to 9 fertile segments, which are cylindrical, $>4 \mathrm{~mm}$ long and $>3$ $\mathrm{mm}$ wide (Fig. 4b). Scarious edge is wider (about $0.4 \mathrm{~mm}$ ) as in $S$. patula. Flowers in the fertile segments are nearly equal in size $(>2 \mathrm{~mm})$ and seeds are not dimorphic.

Plants of $»$ Salicornia veneta morphotype (= S. procumbens subsp. procumbens) have floral characteristics similar to those of S. emerici, however, the plants of this morphotype of S. emerici are less branched, narrowed and 30 to $40 \mathrm{~cm}$ tall. They exhibit a pyramidal form of the shoot, probably shaped by the tidal regime of open seacoasts.

\section{Germination response}

The germination response of seeds from central and lateral seeds in S. patula was different from seeds of S. emerici and S. veneta (Fig.2). The overall highest germination rates and the greatest germination velocity (100\% in 6 to 7 days) were shown for central 

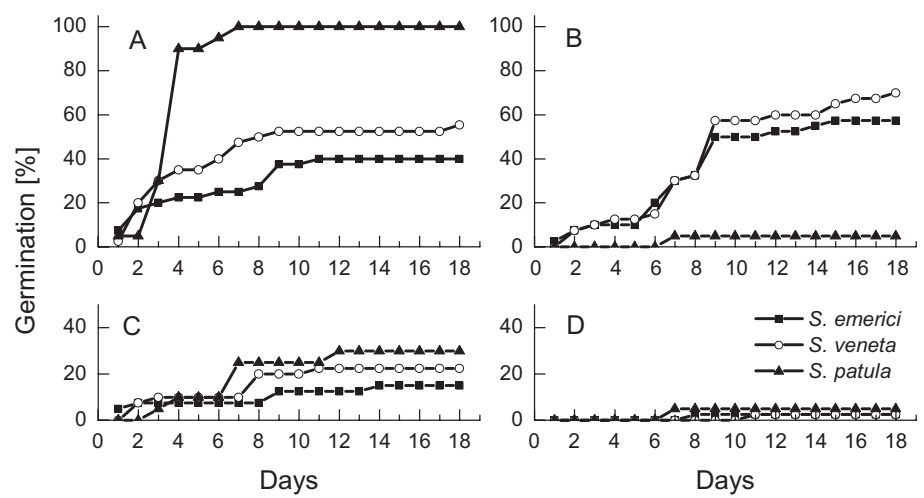

Fig. 2. Germination percentage of main $(A, C)$ and lateral (B, D) seeds in non-saline (A, B) and saline (C, D) condition in Salicornia.

seeds of $S$. patula in non-saline conditions (Tab. 1). Both tetraploid species, with no obvious seed dimorphism, showed a very similar germination pattern: slightly better germination of lateral seeds in deionized water (Fig. 2b) and slightly better germination of the central seed

Tab. 1. Results of germination test in $\mathrm{dH}_{2} \mathrm{O}$ and saline conditions $(340 \mathrm{mM} \mathrm{NaCl})$ for main seeds and lateral seeds of diploid Salicornia patula (= S. perennans) and tetraploids Salicornia emerici and the »Salicornia veneta« morphotype (both synonyms for S. procumbens subsp. procumbens).

\begin{tabular}{|c|c|c|c|c|c|c|}
\hline \multirow{3}{*}{ Time (day) } & \multicolumn{6}{|c|}{ Germination rate of main seed/lateral seed [\%] } \\
\hline & \multicolumn{3}{|c|}{ Conditions: $\mathrm{dH}_{2} \mathrm{O}$} & \multicolumn{3}{|c|}{ Salinity $(340 \mathrm{mM} \mathrm{NaCl})$} \\
\hline & S. emerici & S. veneta & S. patula & S. emerici & S. veneta & S. patula \\
\hline 1 & $7.5 / 2.5$ & $2.5 / 0$ & $5 / 0$ & $5 / 0$ & $0 / 0$ & $0 / 0$ \\
\hline 2 & $17.5 / 7.5$ & $20 / 7.5$ & $5 / 0$ & $7.5 / 0$ & $7.5 / 0$ & $0 / 0$ \\
\hline 3 & $20 / 10$ & $30 / 10$ & $30 / 0$ & $7.5 / 0$ & $10 / 0$ & $5 / 0$ \\
\hline 4 & $22.5 / 10$ & $35 / 12.5$ & $90 / 0$ & $7.5 / 0$ & $10 / 0$ & $10 / 0$ \\
\hline 5 & $22.5 / 10$ & $35 / 12.5$ & $90 / 0$ & $7.5 / 0$ & $10 / 0$ & $10 / 0$ \\
\hline 6 & $25 / 20$ & $40 / 15$ & $95 / 0$ & $7.5 / 0$ & $10 / 0$ & $10 / 0$ \\
\hline 7 & $25 / 30$ & $47.5 / 30$ & $100 / 5$ & $7.5 / 0$ & $10 / 0$ & $25 / 5$ \\
\hline 8 & $27.5 / 32.5$ & $50 / 32.5$ & $100 / 5$ & 7.5 & $20 / 0$ & $25 / 5$ \\
\hline 9 & $37.5 / 50$ & $52.5 / 57.5$ & $100 / 5$ & 12.5 & $20 / 0$ & $25 / 5$ \\
\hline 10 & $37.5 / 50$ & $52.5 / 57.5$ & $100 / 5$ & 12.5 & $20 / 0$ & $25 / 5$ \\
\hline 11 & $40 / 50$ & $52.5 / 57.5$ & $100 / 5$ & 12.5 & $22.5 / 2.5$ & $25 / 5$ \\
\hline 12 & $40 / 52.5$ & $52.5 / 60$ & $100 / 5$ & 12.5 & $22.5 / 2.5$ & $30 / 5$ \\
\hline 13 & $40 / 52.5$ & $52.5 / 60$ & $100 / 5$ & 12.5 & $22.5 / 2.5$ & $30 / 5$ \\
\hline 14 & $40 / 55$ & $52.5 / 60$ & $100 / 5$ & 15 & $22.5 / 2.5$ & $30 / 5$ \\
\hline 15 & $40 / 57.5$ & $52.5 / 65$ & $100 / 5$ & 15 & $22.5 / 2.5$ & $30 / 5$ \\
\hline 16 & $40 / 57.5$ & $52.5 / 67.5$ & $100 / 5$ & 15 & $22.5 / 2.5$ & $30 / 5$ \\
\hline 17 & $40 / 57.5$ & $52.5 / 67.5$ & $100 / 5$ & 15 & $22.5 / 2.5$ & $30 / 5$ \\
\hline 18 & $40 / 57.5$ & $55.5 / 70$ & $100 / 5$ & 15 & $22.5 / 2.5$ & $30 / 5$ \\
\hline
\end{tabular}


in saline conditions (Fig. 2c). In each species the germination rate was inhibited and the germination of lateral seeds was especially slowed down with salinity.
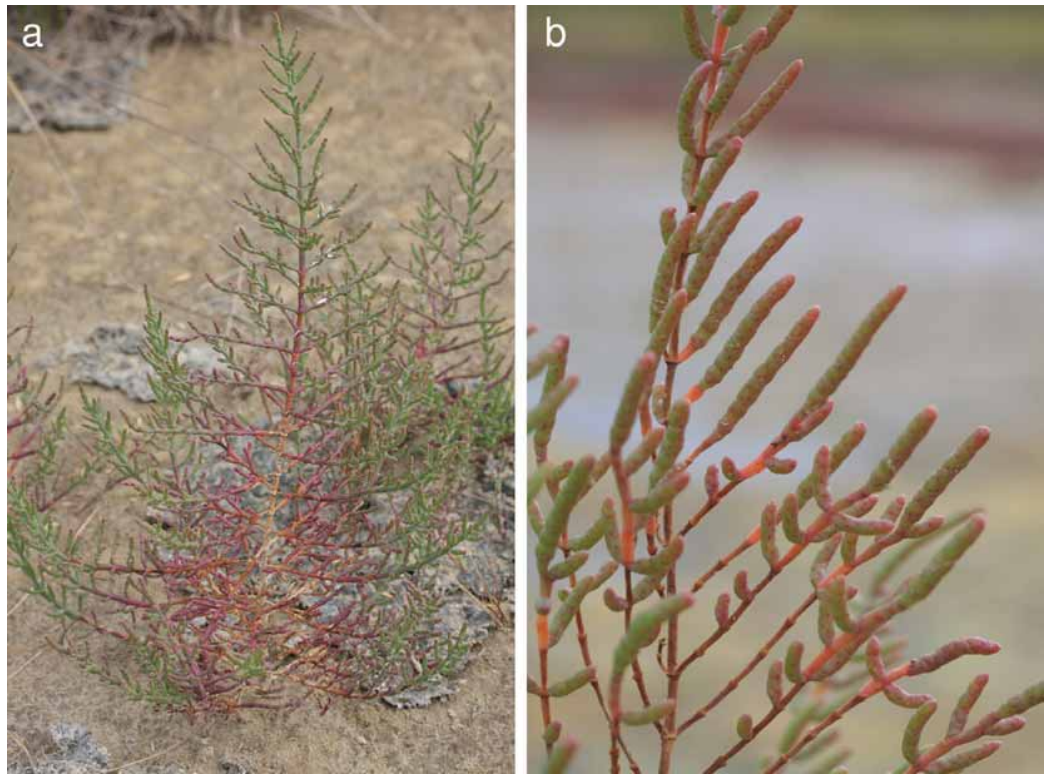

Fig. 3. Plant architecture of Salicornia patula (a) and Salicornia emerici (b).
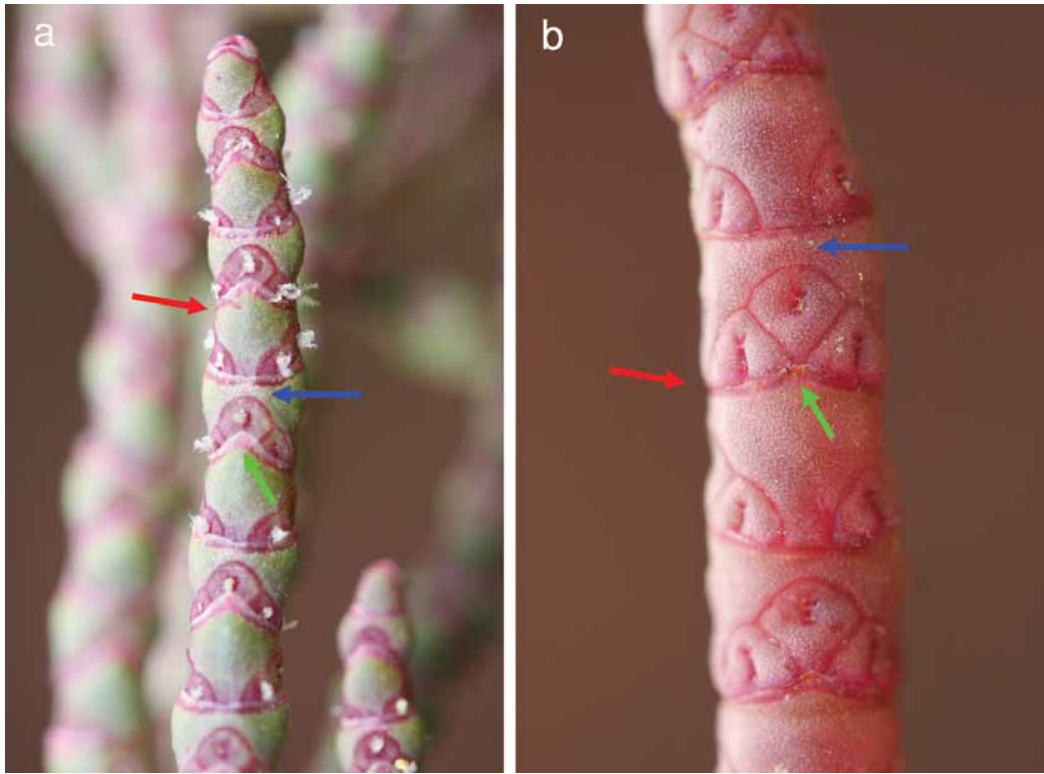

Fig. 4. The differences of the shape (red arrow), length (blue arrow), and the scarious margin width (green arrow) of fertile segments between Salicornia patula (a) and Salicornia emerici (b). 


\section{Phytosociological classification}

Salicornia patula grows on the border or even together with the perennial halophyte stands of Sarcoccornetea fruticosae and Juncetea maritimae. Salicornia patula often forms small stands where it is the dominant species but shows low cover percentage. It grows together with Suaeda maritima, Puccinellia festuciformis, Salsola soda, Sarcocornea fruticosa, Halimione portulacoides, Atriplex prostrata etc. It penetrates stands of Limonio-Artemisietum coerulescentis Horvatić (1933) 1934 and into Puccinellio festuciformis-Arthrocnemetum fruticosi (Br.-Bl. 1928) Géhu 1976 (= Salicornietum fruticosae Br.-Bl. 1928) (PAND A et al. 2007). Small patches of S. patula-dominated stands with Suaeda maritima were also found in the locality Nin - sand dunes and near the estuary of Ljubač. These stands could be attributed to the association Suaedo maritimae-Salicornietum patulae Brullo et Furnari 1976 ex Géhu et Géhu-Franck 1984. This association is cited to be one of the most widespread glasswort associations in the Mediterranean (FRONDONI and IBERITE 2002), but not in the Eastern Adriatic.

Stands of S. emerici are almost monocultures, with some Suaeda maritima, Phragmites australis, Limonium angustifolium aggr. etc. These stands are easily attributed to association Salicornietum emerici O. Bolós ex Brullo et Furnari 1976. Salicornia emerici is also widespread in the Gulf of Trieste (e.g. Grado lagoon, Slovenian coast; own unpublished data). On the Croatian coast this association has been observed in the salt pans of Nin, in the estuaries near Rtina, in salt pans near Dinjiska (Pag) and in the coastal lagoon of Zrče (Pag).

Among the observed glassworts in Croatia we did not find any resembling the $» S$. veneta $\ll$ morphotype.

\section{Discussion}

\section{Taxonomic determination}

Even though Salicornia species show considerable phenotypic plasticity often related to environmental gradients, at least some morphological differences have a genetic basis (TEEGE et al. 2011, VANDERPOORTEN et al. 2011). Our previous study showed that morphometrical data of generative parts of the plants corresponded better with ploidy level as vegetative parts (KALIGARIČ et al. 2008). Additionally, tetraploids and diploids remained easy to recognize after seed shedding, since dried generative shoots of the latter were smaller. Therefore we were expecting some correspondence of seed characteristics with ploidy. However, besides seed dimorphism in $S$. patula no other seed characteristic was useful for species determination. The curving of trichomes used by IBERITE $(1996,2004)$ turned out to be a very doubtful as a diagnostic character, for trichomes vary according to the position on the testa. On each seed we observed straight and spirally curved trichomes and we did not observe any trichome characteristics exclusive to any species.

\section{Germination and habitat preference}

Salicornia patula and S. emerici have a characteristic habitat preference. They occupy different microhabitats and rarely co-occur. Salicornia patula inhabits the upper levels of alluvial mudflats or sandy soils or artificial structures (like ditches in salt pans). This means the driest, hypersaline and nutrient poor stands during summer (JEFFERIES et al. 1979). DAVY and Sмiтн (1985) described a similar distinction in habitats between diploid S. pusilla (now 
S. europaea subsp. europaea; KADEREIT et al. 2012) and the tetraploid pioneer S. dolichostachya further seawards (now S. procumbens susp. procumbens; KADEREIT et al. 2012), along the salt-marsh gradient of the Norfolk coast of Britain. It seems that there is a general rule of habitat distinction between diploids, occupying the upper part, and tetraploids, forming pioneer communities at the lower part of the salt-marsh gradient.

Our results show high germination rate of the central seed and the highest rate among all investigated species, while the lateral, most abundant seeds on the plant, hardly germinated. Central seeds are also more salt tolerant than the same seed type of S. emerici or S. veneta. Lateral seeds are smaller, they are more likely to form a persistent seed bank (CARTER and UNGAR 2003) and represent a source for plant population recovery after drastic disturbance events such as flooding (IMBERT 2002). This could explain the rarity of $S$. patula. Since persistent seeds poorly germinate, the species finds it hard to cope with disturbances and is only able to occupy more stable habitats, even though drought and high saline conditions might prevail. Additionally, more stable habitats are also scarcely distributed and are more frequently anthropogenically affected.

Salicornia emerici inhabits lower parts of the sea-exposed mudflats (avoiding thicker granulates, e.g. sand), often exposed to regular tide regime and rich nutrient flow. The estuaries or muddy shallow coasts are typical natural habitats, while the wet parts of the salt pans are man-made (where technology allows its development). Our germination studies show no differences between the germination rate of the central and lateral seeds of S.emerici, even though the lateral germinate slightly better. However, S.emerici plants released more seeds that germinated per fertile shoot than $S$. patula (around 2 times as many germinating seeds).

\section{Salicornia veneta}

The status of $S$. veneta as a separate species has been clearly put in doubt already by KALIGARIČ et al. (2008), however, KADEREIT et al. (2012) finally classified this taxon as a synonym for $S$. procumbens subsp. procumbens (which includes also $S$. emerici). An addi4tional characteristic contradicting the endemic status of S.veneta, besides molecular analysis and floral morphology, is the incongruence with the assumed restricted Northern Adriatic endemism distribution. Namely, the $\gg$ S. veneta « morphotype was found in several other parts of Italy (IBERITE 1996) and on Sardinia as well (FILIGHEDDU et al. 2000). According to TeEgE et al. (2011), a new species of Salicornia should only be accepted when besides their morphological distinctness, their monophyly has been shown by molecular data. However, synonymizing $S$. veneta could raise several conservation questions, because $S$. veneta has been selected as a flagship species currently listed in Annex I of the Bern Convention (Anonymous 1979) and in the Annex II of the Habitat Directive (AnONYmous 1992).

Even though we recognized $S$. veneta in the field by its pyramidal plant architecture the main certainty of the determination was underlined by the site of plant collection, which was the type locality (locus classicus). Our results (KALIGARIČ et al. 2008) show that generative parts of $S$. veneta are not distinct from tetraploid $S$. emerici (now S. procumbens subsp. procumbens; KADEREIT et al. 2012). Furthermore, here we present the lack of functional distinctness related to germination. Neither germination pattern nor germination rate of the $» S$. veneta morphotype differed from the values observed for S. emerici, either for the main 
seed, or for the lateral seed, irrespective of conditions beng saline or non-saline. These findings suggest that tetraploids »S. veneta « morphotype and $S$. emerici could be described as ecotypes, which was suggested for other tetraploid European Salicornia species by TEEgE et al. (2011). On the other hand, continuous patterns of habitual variation might be explained by the phenotypic plasticity. According to our results plants recognized as $\gg S$. veneta « would be better described as morphotypes since we did not study ecological factors and we did not prove delineation between $S$. emerici and »S. veneta « based on ecological characteristics.

\section{Conclusion}

Considering the new insights given from molecular studies we can so far recognize and confirm only Salicornia emerici (now S. procumbens subsp. procumbens; KADEREIT et al. 2012) and S. patula (now S. perennans Willd.; KADEREIT et al. 2012) as taxa of glassworts present on the Croatian coast. We propose Salicornia veneta should not be retained as a separate taxon and its conservation value should be expanded to the $S$. procumbens group (sensu KADEREIT et al. 2012). We would like accodingly to encourage further phytosociological research on the basis of a new taxonomic delineation, enriched with environmental and functional data.

\section{Acknowledgements}

The authors would like to thank B. Livio for the fieldwork and K. Cafuta for laboratory assistance. The authors acknowledge valuable comments and suggestions of the anonymous referee. The research for this paper was funded by the program group »Biodiversity « (P1-0078) and the research projects J1-6577, L1-7001-006 and P4-0077 all founded by the Slovenian Research Agency.

\section{References}

ANONYMOUS, 1979: Bern convention on the conservation of European wildlife and natural habitats (Bern Convention): Annex I. Council of the European Communities.

AnONymous, 1992: Council Directive 92/43/EEC of 21 May 1992 on the conservation of natural habitats and of wild fauna and flora: Annex II. Council of the European Communities.

Ball, P. W., 1993: Salicornia L. In: WeBB, D. A. (Ed.), Flora Europea, 1. Cambridge University Press, London.

Beer, S. S., Beer, A. S., Sokoloff, D. D., 2010: Flower and inflorescence development in Salicornia (Chenopodiaceae). Feddes Repertorium 121, 229-247.

BERGER, A., 1985: Seed dimorphism and germination behavior in Salicornia patula. Vegetatio $61,137-143$.

CARTER, C. T., Ungar, I. A., 2003: Germination response of dimorphic seeds of two halophyte species to environmentally controlled and natural conditions. Canadian Journal of Botany 81, 918-926. 
Davy, A. J., Bishop, G. F. M., Costa, C. S. B., 2001: Salicornia L. (Salicornia pusilla J. Woods, S. ramosissima J. Woods, S. europaea L., S. obscura P. W. Ball et Tutin, S. nitens P. W. Ball et Tutin, S. fragilis P. W. Ball et Tutin and S. dolichostachya Moss.). Journal of Ecology 89, 681-707.

DAVY, A. J., SmITH, H., 1985: Population differentiation in the life-history characteristics of salt-marsh annuals. Vegetatio 61, 117-125.

DomAC, R., 1984: Flora of Croatia and neighboring areas (In Croatian). Školska knjiga, Zagreb.

DomAC, R., 2002: Flora of Croatia - determination key (In Croatian). Školska knjiga, Zagreb.

Filigheddu, R., Biondi, E., FARris, E., 2000: The vegetation of S'Ena arrubia lagoon (centre-western Sardinia). Fitosociologia 27, 39-59.

FrondONI, R., IBERITE, M., 2002: The halophyte vegetation of sedimentary coasts of Lazio (central Tyrrhenian district, Italy). Plant Biosystems 136, 49-68.

Huiskes, A. H. L., Schat, H., ElenBAas, P. F. M., 1985: Cytotaxonomic status and morphological characterisation of Salicornia dolychostachya and Salicornia brachystachya. Acta Botanica Neerlandica 34, 271-282.

IBERITE, M., 1996: Contribution to the knowledge of the genus Salicornia (Chenopodiaceae) in Italy. Annali di Botanica 54, 145-153.

IBERITE, M., 2004: Le salicornie: metodologie di indagine e problematiche tassonomiche. Informatore Botanico Italiano 36, 508-511.

IMBERT, E., 2002: Ecological consequences and ontogeny of seed heteromorphism. Perspectives in Plant Ecology Evolution and Systematics 5, 13-36.

Ingrouille, M. J., Pearson, J., 1987: The pattern of morphological variation in the Salicornia europea L. aggregate (Chenopodiaceae). Watsonia 16, 269-281.

Ingrouille, M. J., Pearson, J., Havil, D. C., 1990: The pattern of morphological variation in the Salicornia dolychostachya Moss group from different sites in southern England. Acta Botanica Neerlandica 39, 263-273.

JEFFERIES, R. L., DAVy, A. J., RUDNIK, T., 1979: The growth biology of the salt marsh annual Salicornia europaea agg. Journal of Ecology 69, 17-31.

Kadereit, G., Ball, P., Beer, S., Mucina, L., Sokoloff, D., Teege, P., YapraK, A. E., FreiTAG, H., 2007: A taxonomic nightmare comes true: phylogeny and biogeography of glassworts (Salicornia L., Chenopodiaceae). Taxon 56, 1143-1170.

Kadereit, G., Mucina, L., Freitag, H., 2006.: Phylogeny of Salicornioideae (Chenopodiaceae): diversification, biogeography, and evolutionary trends in leaf and flower morphology. Taxon 55, 617-642.

Kadereit, G., Piirainen, M., Lambinon, J., Vanderpoorten, A., 2012: Cryptic taxa should have names. Reflections on the glasswort genus Salicornia (Amaranthaceae). Taxon 61, 1227-1239.

KAligarič, M., Bohanec, B., Simonovik, B., ŠAJnA, N., 2008: Genetic and morphologic variability of annual glassworts (Salicornia L.) from the Gulf of Trieste (Northern Adriatic). Aquatic Botany 89, 275-282. 
Lahondère, C., 2004: Les salicornes s. 1. (Salicornia L., Sarcocornia A. J. Scott et Arthrocnemum Moq.) sur les cotes francaises. Bulletin de la Société Botanique du Centre-Ouest, Nomero Special 24, 1-122.

LAUSI, D., 1969: Descrizione di una nuova Salicornia della Laguna veneta. Nuovo Giornale Botanico Italiano 103, 183-188.

Nikolić, T. (ed.), 2007: Flora Croatica database. Retrieved May 20, 2013 from http://hirc. botanic.hr/fcd.

Nikolič, T., Topić, J., 2004: Vascular flora. In: Nikolić, T., Topić, J. (eds.), Red list of threatened plants and animals of Croatia. State Institute for Nature Protection, Zagreb.

PANDŽA, M., FrAnJIĆ, J., ŠKVORC, Ž., 2007: The salt marsh vegetation on the East Adriatic coast. Biologia 62, 24-31.

Papini, A., Trippanera, G. B., Maggini, F., Filigheddu, R., Biondi, E., 2004: New insights in Salicornia L. and allied genera (Chenopodiaceae) inferred from nrDNA sequence data. Plant Biosystems 138, 215-223.

Stace, C. A., 1997: New flora of the British isles. Cambridge University Press, London.

TeEge, P., KAdereit, J. fW., KAdEREIT, G., 2011: Tetraploid European Salicornia species are best interpreted as ecotypes of multiple origin. Flora 206, 910-920.

Vanderpoorten, A., Hardy, O. J., Lambinon, J., Raspé, O., 2011. Two reproductively isolated cytotypes and a swarm of highly inbred, disconnected populations: a glimpse into Salicornia evolutionary history and challenging taxonomy. Journal of Evolutionary Biology 24, 630-644. 